\title{
Hamman's crunch: a forgotten clue to the diagnosis of spontaneous pneumomediastinum
}

\author{
Andre Rosa Alexandre, Natalia Freitas Marto, Pedro Raimundo
}

Departamento de Medicina Interna e Medicina Intensiva, Hospital da Luz Lisboa, Lisboa, Portugal

\section{Correspondence to} Dr Pedro Raimundo, p_oliveiraraimundo@yahoo.com

Accepted 21 March 2018

\section{DESCRIPTION}

A 23-year-old Caucasian woman with a thin and tall body habitus presented to the emergency department with dizziness and chest pain. The pain had begun 12 hours before presentation without relation to exertion or trauma, radiating continuously to the neck and dorsum and being exacerbated by coughing or taking deep breaths.

The patient was previously healthy except for an episode of flu-like illness 2 weeks before presentation. She was not taking any medication and was a non-smoker. She had no relevant family history.

On clinical examination, she was conscious and reactive, afebrile and haemodynamically stable. She was eupnoeic and her oxygen saturation on pulse oximetry was $100 \%$. Her breath sounds were normal on pulmonary auscultation, but the presence of a crunching sound synchronous with the heart beat was noted on cardiac auscultation (Hamman's sign-video 1). A discrete subcutaneous emphysema was found on palpation of the left supraclavicular fossa. The rest of the physical examination was unremarkable.

The total blood count, renal function, serum sodium and potassium, troponin $\mathrm{I}$ and $\mathrm{C}$ reactive protein were within normal range. The patient's chest radiograph (figure 1) showed an abnormal radiolucent contour around the mediastinal structures, suggesting the presence of a pneumomediastinum. A thoracic CT (figure 2) excluded the presence of coexistent thoracic illnesses, such as structural lung disease or oesophageal perforation, and confirmed the diagnosis of spontaneous pneumomediastinum.

After being assessed by the thoracic surgery team, the patient was admitted to the ward. She was treated conservatively with oxygen therapy, analgesia and avoidance of strenuous physical activity.

There was evidence of nearly complete reabsorption of the pneumomediastinum on the thoracic CT repeated 48 hours after admission. The patient

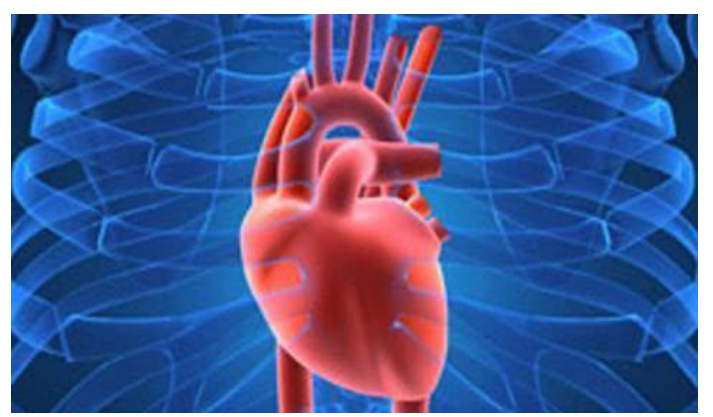

Video 1 Hamman's sign heard at cardiac auscultation.

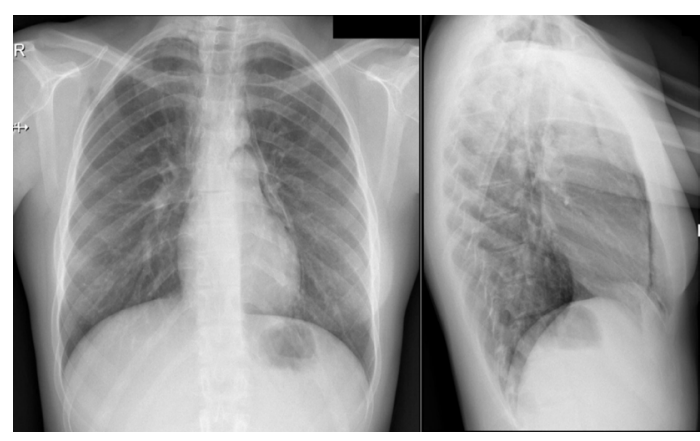

Figure 1 Chest radiograph with an abnormal radiolucent contour around the mediastinal structures.

was discharged home on the next day completely asymptomatic. She has been followed up in our outpatient clinic for 2 years without further events.

This case highlights the importance of a thorough physical examination in the assessment of chest pain. The presence of the Hamman's sign on cardiac auscultation should prompt the consideration of the diagnosis of pneumomediastinum. Spontaneous pneumomediastinum is a rare entity that affects men more frequently than women. ${ }^{1}$ Its peak prevalence is seen in the second to fourth decades of life, especially among tall and thin patients. ${ }^{2}$ A chest radiograph may show signs of the presence of free air on the mediastinum, but the thoracic CT is essential to confirm the diagnosis and to exclude associated thoracic diseases such as gastrointestinal tract perforation or structural lung disease. ${ }^{3}$ Conservative treatment (oxygen, analgesia and avoidance of strenuous physical activity) is usually the preferred approach. The prognosis is typically excellent and the disease self-limited. ${ }^{12}$

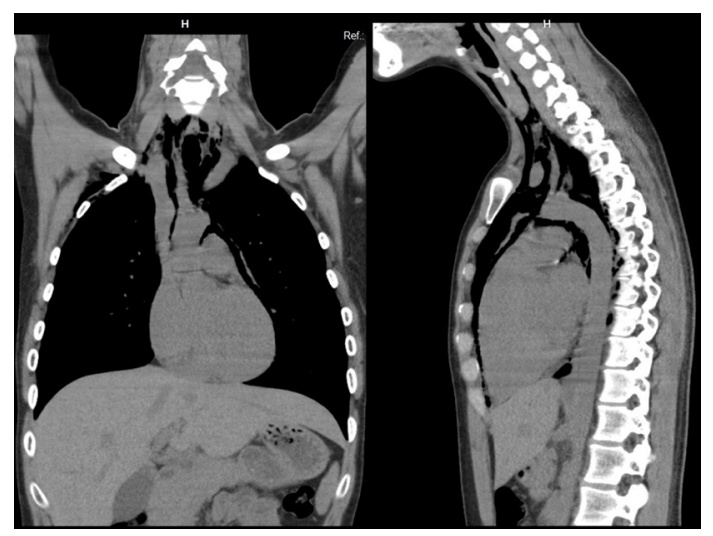

Figure 2 Thoracic CT showing the spontaneous pneumomediastinum. 


\section{Learning points}

- The presence of Hamman's sign on physical examination should prompt the consideration of the diagnosis of pneumomediastinum.

- Thoracic CT is essential to confirm the diagnosis of pneumomediastinum and to exclude concomitant thoracic pathology.

- Conservative approach with oxygen, analgesia and avoidance of strenuous physical activity is the mainstay of treatment of spontaneous pneumomediastinum. The prognosis is excellent.

Contributors ARA wrote the body of the article and learning points. NFM and PR reviewed the whole article.
Funding The authors have not declared a specific grant for this research from any funding agency in the public, commercial or not-for-profit sectors.

Competing interests None declared.

Patient consent Obtained.

Provenance and peer review Not commissioned; externally peer reviewed.

(C) BMJ Publishing Group Ltd (unless otherwise stated in the text of the article) 2018. All rights reserved. No commercial use is permitted unless otherwise expressly granted.

\section{REFERENCES}

1 Song IH, Lee SY, Lee SJ, et al. Diagnosis and treatment of spontaneous pneumomediastinum: experience at a single institution for 10 years. Gen Thorac Cardiovasc Surg 2017;65:280-4.

2 Gasser CR, Pellaton R, Rochat CP. Pediatric Spontaneous Pneumomediastinum: Narrative Literature Review. Pediatr Emerg Care 2017;33:1-6 2.

3 Esayag Y, Furer V, Izbicki G. Spontaneous pneumomediastinum: is a chest X-ray enough? A single-center case series. Isr Med Assoc J 2008;10:575-8.

Copyright 2018 BMJ Publishing Group. All rights reserved. For permission to reuse any of this content visit

http://group.bmj.com/group/rights-licensing/permissions.

BMJ Case Report Fellows may re-use this article for personal use and teaching without any further permission.

Become a Fellow of BMJ Case Reports today and you can:

- Submit as many cases as you like

- Enjoy fast sympathetic peer review and rapid publication of accepted articles

- Access all the published articles

- Re-use any of the published material for personal use and teaching without further permission

For information on Institutional Fellowships contact consortiasales@bmjgroup.com

Visit casereports.bmj.com for more articles like this and to become a Fellow 